Western University

Scholarship@Western

2016

Globalisation and Internationalisation of Teacher Education: A Comparative Case Study of Canada and Greater China

Marianne A. Larsen

Western University, mlarsen@uwo.ca

Follow this and additional works at: https://ir.lib.uwo.ca/edupub

Part of the Education Commons

Citation of this paper:

Larsen, M. A. (2016). Globalisation and internationalisation of teacher education: A comparative case study of Canada and Greater China. Teaching Education, 27(4), 396-409. 


\section{Globalisation and Internationalisation of Teacher Education: A Comparative Case Study of Canada and Greater China}

Marianne A. Larsen ${ }^{1}$

University of Western Ontario, London, Canada

This article begins with a brief overview of the relationship between globalisation and the internationalisation of higher education. This serves as a backdrop for the focus of the article, which is the internationalisation of teacher education. In order to see the diverse ways that teacher education programs have been internationalised over the past 15 years, a case study comparing internationalisation initiatives in Greater China and Canada is presented. This comparative case study demonstrates how different globalising processes influence various forms of internationalisation. Comparison also sheds light on the importance of attending not only to broader, global processes, but specific, local contextual factors. Rather than consider internationalisation as one set of practices that have been taken up globally, this article suggests that there are many different forms of internationalisation in teacher education that are influenced by both global and local contexts. In this respect, the study moves us towards a more nuanced and complex understanding of how teacher education institutions across diverse settings are being internationalised in the $21^{\text {st }}$ century.

\footnotetext{
${ }^{1}$ Contact Details: University of Western Ontario, Faculty of Education, 1137 Western Road, London, Ontario, CANADA N6A 1G7. Email: mlarsen@uwo.ca
} 
Keywords: Canada, global citizenship education; Greater China; globalisation; internationalisation; international practicum; study abroad; teacher education

\section{Introduction}

Internationalisation, "the process of integrating an international, intercultural or global dimension into the purpose, functions or delivery of post-secondary education" (Knight, 2004, p. 11) has become a significant feature of higher education over the past two decades. Indeed, a majority of universities and colleges now view internationalisation as a significant policy strategy and include it as a key goal in their institutional mission statements and strategic plans (Altbach \& Knight, 2007). Teacher education programs, departments, and faculties are no exception to this trend and there is evidence of the internationalisation of teacher education across the globe (e.g. Acedo, 2012; Bégin-Caouette, 2012; Hurtado, Coronel, Carrasco \& Correa, 2013; Low \& Lee, 2012; Lugovtsova, Krawnova \& Torhova, 2012; Madhavi \& Pushpanadham, 2011; Olmedo \& Harbon, 2010; Shaklee \& Bailey, 2012; Tudball, 2012). The internationalisation of teacher education cannot be understood without consideration of the broader processes associated with globalisation. These global transformations have influenced and, to some degree, driven a range of international initiatives implemented in teacher education including the internationalisation of curricula; the growth of international service, field and internship experiences; cross-border initiatives and the increasing use of English as a Medium of Instruction (EMI) in higher education outside of the Anglospeaking world.

This article, drawing upon a wide range of secondary literature and primary documentary sources, is divided into three sections. First, I provide a broad overview of the relationship between globalisation and internationalisation processes in higher education in order to set the stage for a closer examination of these processes within teacher education. In the second section, using a 
comparative, case study methodology, I provide specific details about how teacher education programs have been internationalised in Canada and Greater China. The infusion of multicultural, global and comparative education content into teacher education programs in Canada and Greater China, and increasing cross-border mobility flows of teacher education students are provided as examples of how teacher education programs are internationalised across the two settings. In the discussion section of the paper, I tease out the different ways that globalisation processes have influenced internationalisation in teacher education programs in China and Canada. Specifically, the comparison sheds light on divergences in terms of internationalisation strategies and reveals the need to take into account both local contexts and global transformations to understand contemporary internationalisation in teacher education. Finally, I briefly review some of the tensions, barriers and challenges facing teacher education institutions in moving forward internationalisation agendas, before offering some concluding remarks.

\section{Globalisation and internationalisation of higher education}

The internationalisation of teacher education has been unfolding amidst a range of developments associated with globalisation. Globalisation is understood here as a set of interconnected (and varying) processes that embody "a transformation in the spatial organisation of social relations and transactions, expressed in transcontinental or interregional flows and networks of activity, interaction and power" (Held, McGrew, Goldblatt \& Perraton, 1999, p. 16). Global transformations, which are economic, political and cultural, include the growing global mobility of people; the impact of rapid technological change such as Internet access and the use of social media; related increasing knowledge and information flows; as well as rapid economic changes that necessitate the development of skilled, flexible and mobile labour forces worldwide. 
Higher education institutions (HEIs), as Simon Marginson and Marijk van der Wende (2006) argue, are being transformed by globalisation, partly as victims and partly as agents. The highly mobile nature of information and technology, made possible by the widespread use of the Internet, is one example of how globalisation processes have influenced higher education. Another example is the spread of neo-liberal or new public management reforms that operate in ways to marketise higher education through performance based appraisals, increasing competition between and within institutions, and pressures to reduce costs through the commodification of research outputs.

Within this global context, we see the processes of internationalisation of higher education unfolding. There are numerous ways to think of the relationship between globalisation and internationalisation. Some authors assert that the internationalisation of HEIs is both a response to and agent of globalisation (Altbach, 2004; Stromquist, 2007). Others claim that the relationship between the two is dialectical, especially given the much longer history of internationalisation in universities (Marginson \& van der Wende, 2006). Whatever approach one takes, it is impossible to understand internationalisation processes without attending to the broader global transformations that now characterise our modern world.

As a result, we now see increasing attention paid to a wide range of strategies that enable HEIs to develop and strengthen relations across national borders. These include the recruitment of international students, internationalising the curriculum, study abroad and other international experiential experiences, faculty and student mobility, international research partnerships, global rankings, and international and intercultural extracurricular programming (Altbach \& Knight, 2007; Larsen, 2016; Marginson \& van der Wende, 2006; Stromquist, 2007). Teacher education is not immune to these internationalisation trends in higher education, as the following comparative case study between Canada and Mainland China will show. 


\section{Internationalising teacher education: A comparative case study}

In this section, I use a case-study approach to compare the complex and differential ways that teacher education programs have been internationalised in two, distinct settings. Case study methodology enables us to deepen our understanding of complex social phenomena in contemporary contexts, and in particular to understand education-society relations (Arnove \& Torres, 2012). I draw primarily upon the work of Robert Stake (1988) who defines case study as "a study of a bounded system, emphasising the unity and wholeness of that system, but confining the attention to those aspects that are relevant to the research problem at the time" (p. 258). The two cases are teacher education internationalisation initiatives in Canada and in Greater China (Mainland China, Taiwan, Hong Kong and Macao). This is an instrumental case study in that it involves examining two cases in order to provide insight into the specific ways that internationalisation is played out in teacher education programs (Stake, 1994). Furthermore, as a comparative case study it extends and deepens our knowledge of the complexities and differential ways that teacher education programs have been internationalised across diverse settings.

\section{Teacher education in Canada}

Before beginning to review how teacher education programs have been internationalised in Canada, it is important to note that education is under provincial jurisdiction. Hence, there are different teacher education programs for each of the 10 provinces and 3 territories. While there are differences in terms of the curriculum offered in different programs, generally speaking, students become qualified to teach by completing an undergraduate degree, and a concurrent or consecutive Bachelor of Education degree in a university-based faculty of education. Currently, there are 51 universities and university colleges that offer teacher education programs in Canada (http://resource.educationcanada.com/foe.html). 
The recently released Association of Canadian Deans of Education (2014) 'Accord on Internationalization of Education' attests to the fact that internationalisation is at the forefront of teacher education in Canada. One of the main factors to account for this is the fact that linguistic, cultural and racial diversity has become a salient feature of the school environment due to changing demographics in Canadian society (Ryan, Pollock, \& Antonelli, 2009). Canada is a multicultural society whose ethno-cultural make-up has been shaped over time by the First Nations, Metis and Inuit populations, as well as immigrants and their descendants. Almost one in five people identifies themselves as a member of a visible minority group, with $31 \%$ born in Canada, and $65 \%$ born outside the country who have come to live in Canada as immigrants (Statistics Canada, 2013).

The multicultural nature of Canadian society has contributed to increasing awareness about the importance of infusing the public school curriculum with material reflective of the diversity and global origins of the population. A review of curricula across the Canadian provinces and territories reveals broad and increasing support for many of the skills, themes and issues associated with multicultural, global education and global citizenship education (Broom, 2015; Evans, 2006; Larsen, 2009; Mundy, Manion, Masemann \& Haggerty, 2007). The Ontario school curriculum contains numerous examples of outcomes related to preparing students to live in a global world and become global citizens. For example, elementary school students are expected to develop a sense of themselves "locally, nationally and globally" (Ontario Ministry of Education, 2009, p. 8); and use "information and communications technologies to connect students to other schools, at home and abroad, and to bring the global community into the local classroom" (Ontario Ministry of Education, 2007, p. 42).

Canadian teacher education institutions have responded to the imperative to prepare teachers who are able to effectively address issues related to globalization, racism, diversity, and social justice, and foster an equitable and inclusive learning environment for all students. Across the country, most teacher education programs now offer curriculum content variously called 
multicultural, culturally responsive, intercultural, equity, anti-racist, global and/or global citizenship education. For example, in 2009, UNICEF Canada developed and delivered global education pedagogy in teacher education programs across the country through its Global Classroom program. Nine Canadian universities participated in the program from across four provinces (Prince Edward Island, Ontario, Quebec, and British Columbia), which resulted in over 100 workshops, reaching thousands of prospective teachers, practicing teachers and professors. In addition, eleven resource guides were developed to assist teachers in implementing global education pedagogy into their classrooms² (UNICEF Canada, 2013).

The Faculty of Education at the University of Prince Edward Island was one such university that participated in this collaborative program with UNICEF. Linyuan Guo's (2014) study of the 'Educating for Global Citizenship' undergraduate course demonstrates the opportunities and challenges teachers face in learning to educate for global citizenship and suggests the necessity of integrating global citizenship education in teacher education programs through a holistic approach. More recently, other Canadian universities have developed such holistic approaches in preparing educators to teach in a globalised world. One recent example is the new, 2 year International Education Bachelor of Education cohort program at the University of Western Ontario, which aims to provide students with the skills, knowledge, and inter-cultural capacities to teach in international and culturally-diverse school settings through courses related to international education, global citizenship education, inter-cultural communication and teaching abroad (Western Education, 2015).

\footnotetext{
2 These included 'Educating for Global Citizenship: a Practical Guide for Schools in Atlantic Canada', Educating for Global Citizenship - K-8 and 8-12 (British Columbia), Children's Rights in Education: Applying a RightsBased Approach to Education (Ontario), and in Québec « L'éducation à la citoyenneté dans une perspective mondiale: un guide pratique pour la formation universitaire en éducation préscolaire et en enseignement primaire au Québec » and "L'éducation à la citoyenneté dans une perspective mondiale : un guide pratique pour la formation universitaire en enseignement secondaire au Québec » (UNICEF, 2012).
} 
The latter approach, teaching abroad, has become very popular amongst teacher education programs across Canada. As one respondent in Harkins and Barchuk's 2015 study about the influences of an alternative, international practicum on initial teacher education students explained, "When these alternative practicum placements came out, there was a mad rush for signing up...I think that speaks to how much interest there is out there among the student population in the education program, to try something new" (Quoted in Harkins \& Barchuk, 2015, p. 300). International teaching and service opportunities within teacher education programs are generally short-term (e.g. 2-6 weeks) teaching abroad experiences and in some cases, international service learning where student teachers volunteer in settings outside of traditional classrooms (Hurtado et al., 2013; Walters, Garii, \& Walters, 2009). Over half of the Faculties of Education across the country offer their initial teacher education students opportunities to engage in practice teaching abroad. ${ }^{3}$

Research about international practicum placements for Canadian teacher education students reveals the personal and professional benefits that stem from these experiences. These include expanded worldviews, deeper and more critical understanding of global interdependence, and awareness of different educational systems. In terms of teaching, these experiences have been found to enhance student teachers' empathy and sensitivity towards others, and develop culturally responsive, differentiated instruction. There are personal benefits as well including the development of resourcefulness, resilience, confidence, critical thinking, and problem solving, as well as opportunities for learning about racial identities and recognising privilege. Finally, alternative international practicum placements enhance student-teachers abilities to meet the

\footnotetext{
${ }^{3}$ In Ontario, almost three-quarters of faculties/schools of education offer students the opportunity to engage in alternative, international teaching/service practicum placements.
} 
needs of diverse learners through culturally sensitive teaching strategies at home, and also provide expanded international teaching opportunities (Cantalini-Williams \& Tessaro, 2011; Grierson \& Denton, 2013; Harkins \& Barchuk, 2015; Maynes, Allison \& Julien-Schultz, 2013; Mwebi \& Brigham, 2009; Trilokekar \& Kukar, 2011).

\section{Greater China}

As noted above, Greater China consists of Mainland China, Taiwan, Hong Kong and Macau. ${ }^{4}$ In Mainland China, there are three types of teacher education institutions: secondary teachers' schools to prepare students to become teachers in primary and pre-school education; normal colleges to prepare teachers for junior-secondary schools; and the normal university, which is a four-year undergraduate university that issues bachelor's degrees and prepares teachers for senior-secondary schools. In 2003, there were 430 secondary teachers schools and 188 normal colleges and universities in Mainland China, as well 3 Normal universities in Taiwan. In Hong Kong, teacher education is offered at comprehensive universities with faculties of education (the Chinese University of Hong Kong, and the University of Hong Kong) and at the Hong Kong Institute of Education. In Macau, there is one teacher education institution at the University of Macau (Li \& Bray, 2007; Manzon, 2008). Both concurrent and consecutive pathways of initial teacher education serve to prepare primary and secondary teachers.

Unlike Canada, the governance of education is highly centralized in each territory and, as such, there are national curriculum guidelines. There is a growing concern for issues related to global education in the school curriculum, even though the term itself is not commonly used. Related

\footnotetext{
${ }^{4}$ The 2015 estimated population of Mainland China is 1.376 billion, Taiwan 23.5 million, Hong Kong 7.42 million; and Macau 643, 000. Given their relative sizes, I focus here primarily on Mainland China, Taiwan and Hong Kong. (Note: By way of comparison, Canada's population is estimated to be 35.76 million in 2015.)
} 
curricular emphases include international awareness, international understanding, the global environment, globalization of the economy and the Internet era. During the 1990s, the national curriculum in China further emphasised international studies, world history, and world geography with a focus on current world issues. As in Canada, the science curriculum now focuses on the relationships between humans and the environment, as well as ethics in science and global interdependencies (Departments of Education, 1998; Tye, 2004).

In response to these changes to the national curriculum, efforts have been made to internationalise teacher education programs. For example, in Beijing, the Project of Education for International Understanding was established in the late 1990s to include topics related to international awareness and understanding in teacher education (Tye, 2004). While this is a relatively new initiative, teacher education programs in Greater China have a longer and more sustained emphasis on comparative education. As early as the 1980s, comparative education was introduced to bachelors' programmes at normal universities or departments of education in comprehensive universities in China (Wang, Dong \& Shibata, 2009). In some normal universities, undergraduate students majoring in education are required to take a comparative education course in their third year. The purpose of teaching comparative education in Mainland China is that it is "concerned with the comparative analysis of education in different countries/regions of the world, so that we can identify general and specific principles in educational development" (Mingyuan, 2001, quoted in Manzon, 2008, p. 217). Comparative education courses are also offered at Taiwanese teacher education programs. For example, specialist comparative education courses are taught at the National Taiwan Normal University and the National Kaohsiung Normal University. In Hong Kong, a "vigorous and visible" institutionalization of comparative education has taken place in faculties of education at the Chinese University of Hong Kong and the Hong Kong University (Manzon, 2008, p. 220). 
There is also another instantiation of internationalisation in Greater China that has rapidly changed the face of public education and teacher education over the past ten years. This is the push for Chinese citizens to learn English and, to this end, there has been tremendous growth in private language schools and policy changes mandating the teaching of English in all public schools in Mainland China starting in the second grade (McPherron, 2008). As a result of these changes in school-based education, internationalised English teacher education programs have spread rapidly across many East-Asian countries (Porter, 2011). While Chinese is the official language in all four territories that comprise Greater China, English is an official language alongside Chinese in Hong Kong. That being said, English has "retained its dominance as a vehicle for international academic discourse in all four societies of Greater China" (Manzon, 2008, p. 212).

McPherron's (2008) doctoral dissertation clearly documents how reforms at one university in southern China are closely tied to national attempts to increase the number and spoken fluency of English speakers in an effort to internationalise Chinese education and meet the growing need for bilingual Mandarin-English and trilingual Mandarin-Cantonese-English school managers. In recent years, the university mandated that all students take English through a newly created English Language Department, and it has recruited many foreign experts to teach new courses specifically using communicative language teaching methods.

Some universities have developed collaborative programs to prepare their student teachers for teaching English as a second language. For example, a university in Shanghai has developed a program in collaboration with the University of Sydney for teaching post-graduate coursework through an institutional agreement to offer a Master of Education in China. Chinese students enrolled in the program engage in face-to-face contact with native English-speaking lecturers as a part of their educational experiences (Olmedo \& Harban, 2010). However, the most popular route for Mainland Chinese initial teacher education students to learn English is by completing their teacher training in Hong Kong. The government of Hong Kong has actively encouraged post- 
secondary institutions to recruit students from the Chinese Mainland to train them as Englishlanguage teachers (Gu, 2013b; Trent \& DeCoursey, 2011). Once they have completed their training, these language teachers are entitled to be employed in Hong Kong primary and secondary schools to address the existing teacher shortage there (Gu, 2013b).

\section{Discussion}

In this section, I relate the internationalisation initiatives that have been implemented in Chinese and Canadian teacher education programs to both macro processes associated with globalisation, and local contextual factors. This comparison also shows how we can broaden our understanding of the internationalisation of teacher education by taking into account specific, local contexts in our analysis of this phenomenon. That being said, it is important to acknowledge the limitations of case study methodology especially in terms of the generalisability of findings. The point here is not to suggest that the internationalisation initiatives taking place in Chinese and Canadian teacher education programs are commonplace world-wide, but precisely the opposite: that internationalisation looks different across diverse settings and we cannot understand these processes without reference to both local and global contexts.

Similar to global trends in higher education, we can see how economic drivers are facilitating the internationalisation of teacher education. In this scenario, internationalisation is considered a response to the growing global pressures of neo-liberal economic competition. Newly trained teachers are expected to prepare their own students with the skills, knowledge, and competencies to compete in the global marketplace (Li \& Bray, 2007; Tudball, 2012), and this has contributed to changes in curricular content related to international education in initial teacher education programs.

Opportunities to engage in (practice) teaching and study abroad through teacher education 
can be viewed as manifestations of economic globalisation. It is in this light that we better understand the cross-border mobility of both student teachers and qualified teachers, which is connected to pressures to engage in flexible, transnational employment, a key characteristic of the neo-liberal globalised economy of the $21^{\text {st }}$ century. On the one hand, there are internationally educated teachers (IETs) who move to other countries, generally on a permanent basis, with the intention of teaching in the new setting (Goodwin, 2010; Walsh \& Brigham, 2008). Many of these cross-border teachers enter local teacher education programs in order to obtain local credentials or upgrade their teaching skills (Chassels, 2010).

In the case of student teachers who do not yet have their formal teaching qualifications, opportunities to teach abroad better position them for teaching in international contexts. As described above, increasing numbers of Canadian student teachers are choosing to participate in international practicum placements in order to enhance their career options and teaching abroad opportunities, a phenomenon exacerbated by the lack of permanent teaching positions in many provinces brought about by demographic and economic changes (Harkins \& Barchuk, 2015). This reflects findings from the study abroad/service learning literature about the personal motivations amongst university students to engage in overseas study and service internships to improve their CVs, test an academic background or career choice (Tiessen, 2012).

Similarly, Li and Bray (2007) discuss the push-pull factors that have contributed to increasing numbers of Mainland Chinese student teachers studying in Hong Kong and Macau. According to their findings, the acquisition of internationally recognised qualifications and English language skills through study-abroad is motivated by estimated economic returns and increased prospects for employment. In addition, the Hong Kong government promotes the recruitment of Mainland Chinese students to "attract talent and diversify the student population for global economic competition and a knowledge-based society" (Li \& Bray, 2007, p. 798). In this respect, teacher student mobility can be understood within the macro context of economic globalisation 
within which governments and institutions are eager to develop programs that enhance international alliances, partnerships and resources.

Cross-border mobility of student teachers and the internationalisation of teacher education curricula are also closely related to processes of cultural globalisation. Cultural globalisation refers to the transmission of ideas, meanings and values around the world to extend and intensify social relations (James, 2006). Cultural flows enable individuals to partake in extended social relations that cross national and regional borders, contributing to ideas such as the global village and global mélange (Pieterse, 2003). The circulation of cultural artifacts, values and beliefs around the world has the potential to increase and enhance interconnectedness and cross-cultural understanding.

The lens of cultural globalisation allows us to understand contemporary efforts to infuse Canadian teacher education courses with cross-cultural, multicultural, and global (citizenship) education content. This is related specifically to the need for educators who are trained to respond to the needs of a linguistically and culturally diverse school population as in the case of Canada. With this example, we see how both macro cultural globalisation processes and local factors such as federal immigration policies have shaped Canada as one of the most culturally diverse societies in the world. Thus, efforts to internationalise school and teacher education curriculum need to take into account the specific history associated with the diversification of Canadian society and related need to prepare teachers who are able to meet the needs of diverse learners.

A closer look at the internationalisation of teacher education curriculum in China reveals a different phenomenon. Since the 1980s, as noted above, comparative education has played a vital role in teacher education programs across Greater China with an emphasis on comparative, pedagogical studies, which aim to teach students about education in other countries. Indeed, as Wang, Dong and Shibata (2009) assert, "the last two decades have witnessed an unprecedented stage of development in Chinese comparative education" (p. 1213), which have had much influence 
on teacher education programs across the region. The inclusion of courses with comparative education content into teacher education programs has a much longer, contemporary history in China compared to Canada where there has been an absence of comparative education courses in teacher education programs since the 1970s (Larsen, Majhanovich \& Masemann, 2007). The reasons for this are complex and cannot be understood without reference to China's open-door policy during the 1980s when there was a concerted effort to reform Chinese education to align with Deng Xiaoping's call for education to be oriented towards "modernization, world, and the future" (Quoted in Wang et al., 2009, p. 1213). Hence, the inclusion of comparative education content in teacher education programs, which is viewed here as a indicator of internationalisation in Chinese teacher education, is related to both broader cultural globalisation processes, as well as national socio-economic and political shifts that China underwent following the Great Cultural Revolution.

Furthermore, we can view the trend across many non-English speaking countries to include English as a medium of instruction (EMI) in higher education as a manifestation of both local/national demands and broader cultural globalising processes that position English as a lingua franca that provides trans-national cultural, economic and symbolic capital (Bourdieu, 1991). For example, the infusion of EMI in teacher education programs in Hong Kong teacher education programs reflects its colonial connections to Great Britain, 'one-country-two systems' relationship with China, and the global hegemony of English in international academic discourse (Altbach, 2007; Li \& Bray, 2007). Moreover, the latter cannot be understood without reference to the impact of global rankings on higher education in which a single, Western standard is promoted within HEIs. The pursuit of 'world-class status' is aligned with the increasing use of English both in research and teaching (Larsen, 2016). While most of the emphasis in global rankings is on strengthening research productivity, the example of teacher education internationalisation in Hong Kong also 
attests to institutional privileging of English over Cantonese in response to demands to strengthen the use of English in public schools.

\section{Internationalising teacher education: Tensions, barriers and challenges}

In this last section, I briefly note some of the tensions, barriers and challenges stemming from internationalisation processes in teacher education, keeping the focus on student-teacher mobility and the internationalisation of the curriculum. First, there are other institutional barriers such as the perception amongst university administrators of the logistical challenges in offering international opportunities (Hurtado et al., 2013; Schneider, 2003). With reference to the United States, Goodwin (2010) asserts that, "the practice of teacher preparation has remained remarkably stable over the past century" and the culture of teacher education highly resistant to new ways of conceiving knowledge (p. 28). Resistance to internationalisation stems from a long-standing belief that teacher education programs should prepare educators to teach locally. Indeed, one of the greatest challenges to the internationalisation of teacher education is that local demands more often than not trump international or global demands (Sieber \& Mantel, 2012). Traditionally, teacher education programs have been mandated to prepare individuals to teach locally and moves to internationalise teacher education clash with this basic aim of teacher education. The expectation, in some jurisdictions, that student teachers complete all of their practice teaching in the local setting in order to qualify for certification is one such example of this parochialism (Schneider, 2003; Walters et al., 2009).

However, despite claims of parochialism, we have seen from the case study above that many teacher education institutions have actually responded to macro-processes associated with cultural and economic globalisation by internationalising their curricula and providing students with opportunities to study and teach abroad. While in North America there is widespread support for 
multicultural and global education in schools, critics fear that efforts to internationalise schools are a threat to national unity, operating in ways to indoctrinate students into a "new world order advocating pacifism, moral relativism, opposition to nationalism via free-market economies, and redistribution of wealth to Third World nations" (Roberts, 2007, p. 10). Such fears speak to the tensions associated with internationalising teacher education and conflation of these processes with economic forms of globalisation.

Moreover, while student-teachers themselves may recognise the importance of becoming more enlightened educators through global and comparative education curricula, Inbar-Lourie and Donitsa-Schmidt's (2013) research on the 'Englishization" of Israeli teacher education colleges demonstrates that student teachers are not always enthusiastic about efforts to internationalise their program. In fact, many of the student teachers in their study were not keen to learn English, even though they expressed a desire to improve their English language skills. Other research also shows that students engaging in international teaching practicum placements face language barriers stemming from challenges related to teaching non-English speaking students and communicating in an unfamiliar language (Cantalini-Williams \& Tessaro, 2011; Trilokekar \& Kukar, 2011).

Furthermore, research has shown how international teaching experiences can be risky and uncertain for student teachers as they experience significant moments of discomfort and disorienting dilemmas in confronting issues of identity, race and privilege (Trilokekar \& Kukar, 2011). Similarly, various studies on Mainland Chinese teacher education students who complete their English-language teacher training in Hong Kong discuss the identity conflicts that arise for these students. For instance, Mainland Chinese student teacher participants in Gu's (2013b) study, "found their existing cultural identity to be unacceptable [in Hong Kong] and incompatible with their new context, and were forced to renegotiate and re-assess it" (p. 419). Similarly, Trent and DeCoursey's (2011) study revealed the challenges to identity formation processes, including the 
"blockage of identity" amongst Mainland Chinese student-teachers who remain in Hong Kong to teach after completing their English-language teacher education program.

There are other tensions and challenges associated with overseas teaching and service placements. Existing research demonstrates that these experiences can provoke many negative emotions such a loneliness, fear, isolation and frustration, and in a few cases lead to illnesses (Gu, 2013a, Hurtado et al., 2013). Furthermore, some service and teaching abroad programs actually reinforce negative stereotypes about the host culture (Walters et al., 2009). There is ample research on study and service abroad that demonstrates the damaging consequences of well-intentioned students who participate in these programs. Many critics question whether students who are studying abroad or engaged in service are actually meeting the needs of the local, host community, and suggest that these international experiences are much more self-serving than altruistic (Heron, 2007; Tiessen, 2012).

Finally, there are financial costs associated with integrating new curricula, such as international education courses or programs, into existing teacher education programs. This is related to the perennial problem of the already over-crowded curriculum in teacher education programs (Schneider, 2003). Moreover, international teaching and service experiences can be risky, expensive and time-consuming, and therefore exclude those who are unable to participate due to financial barriers and lack of time (Maynes et al., 2013). The result of this is that flows of student teachers participating in international practicum placements continue to be from Global North countries such as Canada, illustrating the unequal ways that internationalisation is played out in teacher education programs globally.

\section{Conclusion}


This article has attempted to tease out the complex and context-bound relationship between globalisation and internationalisation of teacher education. I began with a broad overview of the relationship between processes associated with globalisation and higher education internationalisation. Through a comparative case study, I then focused in on specific manifestations of teacher education internationalisation in Canada and Greater China. I reviewed the ways in which teacher education curriculum has been internationalised in Canadian teacher education programs through the infusion of multicultural, global and global citizenship education content with the aim to better meet the needs of diverse learners in the multicultural school settings that characterise Canadian society. I compared this to the inclusion in Chinese teacher education programs on comparative education course content, with its emphasis on learning about education in other societies.

I also reviewed ways in which teacher education programs in Greater China and Canada have been internationalised through student-mobility opportunities. Again, differences are apparent and reflect the inter-relationships between global processes and local contexts. In Canada, teacher education students are increasingly participating in international practicum experiences. Mainland Chinese students have been going to Hong Kong universities to attend teacher education programs where EMI. In both cases, student teachers are motivated by desires to accrue cultural, social and symbolic capital in order to better position themselves within the job market and compete in the global economy. In both cases, students are also motivated by desires to better understand themselves and their diverse societies by participating in social and cultural experiences away from 'home'.

Clearly, transformations related to cultural and economic globalisation have been influencing teacher education programs across diverse contexts. A comparison of the specific ways that teacher education programs have been internationalised in two different settings, Greater China and Canada, sheds light on the importance of attending not only to broader, global processes, 
but specific, local contextual factors. Yet, while we can see how teacher education programs have responded both to local and global imperatives, it is also worth noting the potential of internationalised forms of teacher education to act as key agents of globalisation, an area that demands much more empirical, comparative research.

\section{References}

Acedo, C. (2012). Internationalization of teacher education. Prospects, 4, 1-3.

Altbach, P. G. (2004). Globalisation and the university: Myths and realities in an unequal world. Tertiary Education and Management, 10(1), 3-25.

Altbach, P.G. (2007). The imperial tongue: English as the dominating academic language. International Higher Education, 49, 2-4.

Altbach, P. G., \& Knight, J. (2007). The internationalization of higher education: Motivations and realities. Journal of Studies in International Education, 11(3-4), 290-305.

Arnove, R.F. \& Torres, C.A. (Eds.). (2012). Comparative education: The dialectics of the global and the local. Lanham: Rowman \& Littlefield.

Association of Canadian Deans of Education (ACDE) (2014). Accord on the internationalization of education. Retrieved from http://www.csse$\underline{\text { scee.ca/docs/acde/Accord_Internationalization_EN.pdf }}$

Bégin-Caouette, O. (2012). The internationalization of in-service teacher training in Québec cégeps and their foreign partners: An institutional perspective. Prospects, 42(1), 91-112.

Bourdieu, P. (1991). Language and symbolic power. Cambridge: Polity Press.

Broom, C. (2015). Social studies in three Canadian provinces: A comparative exploration. 
Comparative and International Education/Éducation Comparée et Internationale, 44(1), Article

4.

Cantalini-Williams, M. \& Tessaro, M.L. (2011). Teacher candidates' perceptions of an international practicum experience in Italian schools: Benefits of a short-term placement with faculty support. Comparative and International Education/Éducation Comparée et Internationale, 40(3), Article 5.

Chassels, C. (2010). Participation of internationally-educated professionals in an initial teacher education bachelor of education degree program: Challenges and supports. Canadian Journal of Educational Administration and Policy, 100, 1-39.

Departments of Education of New Brunswick, Newfoundland and Labrador, Nova Scotia and Prince Edward Island (1998). Foundations for the Atlantic Canada science curriculum. Retrieved from http://www.ednet.ns.ca/files/curriculum/camet/foundations-science.pdf

Evans, M. (2006). Educating for global citizenship in schools: Contrasting perspectives and practices. Toronto: OISE/UT.

Goodwin, A. L. (2010). Globalization and the preparation of quality teachers: Rethinking knowledge domains for teaching. Teaching Education, 21(1), 19-32.

Grierson, A. \& Denton, R. (2013). Preparing Canadian teachers for diversity: the impact of an international practicum in rural Kenya. In L. Thomas (Ed.), What is Canadian about teacher education in Canada? Multiple perspectives on Canadian teacher education in the twenty-First Century? (pp. 187-210). Ottawa: CATE.

Guo, L. (2014). Preparing teachers to educate for $21^{\text {st }}$ century global citizenship: Envisioning and enacting. Journal of Global Citizenship \& Equity Education, 4(1), 1-23. 
Gu, M.M. (2013a). From pre-service to in-service teachers: a longitudinal investigation of the professional development of English language teachers in secondary schools. Educational Studies, 39(5), 503-521.

Gu, M.M. (2013b). Cultural identity in teaching across borders: Mainland Chinese pre-service students in Hong Kong. Asia Pacific Journal of Education, 33(4), 407-423.

Harkins, M.J. \& Barchuk, Z. (2015). Changing landscape in teacher education: The influences of an alternative practicum on pre-service teachers concepts of teaching and learning in a global world. In L. Thomas \& M. Hirschkorn (Eds.) Change and Progress in Canadian Teacher Education: Research on recent innovations in teacher preparation in Canada (pp. 283-314). Canadian Association of Teacher Educators.

Held, D. McGrew, A., Goldblatt, D., \& Perraton, J. (1999). Global transformations: Politics, economics and culture. Stanford: Stanford University Press.

Heron, B. (2007). Desire for development: Whiteness, gender and the helping imperative. Waterloo, ON: Wilfrid Laurier University Press.

Hurtado, I. G., Coronel, J. M., Carrasco, M. J., \& Correa, R. I. (2013). Internationalization of the practice in education degree: Students' intercultural experiences in the teaching and learning process at Sahrawi refugee camps. Journal of Education and Learning, 2(1), 253-261.

Inbar-Lourie, O. \& Donitsa-Schmidt, S. (2013). Englishization in an Israeli teacher education college: Taking the first steps. In A. Doiz, D. Lasagabaster, \& J.M. Sierra (Eds.) English-Medium Instruction at Universities: Global Challenges (pp. 151-162). Multilingual Matters.

James, P. (2006). Globalism, nationalism, tribalism. London: Sage Publications.

Knight, J. (2004). Internationalization remodeled: Definition, approaches, and rationales. Journal of Studies in International Education, 8(1), 5-31. 
Larsen, M. A. (2009). Global education in Canada: Opportunities and challenges of teaching in the global moment. In W. Russell (Ed.), The international society for the social studies annual conference proceedings (pp. 32-37). Orlando, FL: The International Society for the Social Studies.

Larsen, M.A. (2016). Internationalization of higher education: Space, networks, and mobilities, New York: Palgrave Macmillan.

Larsen, M.A., Majhanovich, S. \& Masemann, V. (2007). Comparative education in Canadian universities. Canadian and International Education//Éducation Comparée et Internationale, 36(3), 15-30.

Li, M. \& Bray, M. (2007). Cross-border flows of students for higher education: Push-pull factors and motivations of Mainland Chinese students in Hong Kong and Macau. Higher Education, $53,791-818$.

Low, E. L., \& Lee, S. K. (2012). Bringing Singapore's teacher education beyond its shores. Educational Research for Policy and Practice, 11(1), 43-51.

Lugovtsova, A., Krasnova, T., \& Torhova, A. (2012). Internationalizing teacher education: The case of Belarus. Prospects, 42(1), 71-90.

Madhavi, R.L. \& Pashpanadham, K. (2011). Teacher education programs in SAARC countries: A comparative study. International Forum of Teaching and Studies, 7(2), 32-49.

Manzon, M. (2008). Teaching comparative education in Greater China: Contexts, characteristics and challenges. In C. Wolhuter \& N. Popov (Eds.), Comparative education as discipline at universities worldwide (pp. 211-228). Sofia, Bulgaria: Bureau for Educational Services.

Marginson, S. \& van der Wende, M. (2006). Globalisation and education. Paris: OECD. Retrieved from http://www.oecd.org/edu/research/37552729.pdf 
Maynes, N., Allison, J. \& Julien-Schultz, L. (2013). An examination of longevity of impact of an international practicum experience on teachers' beliefs and practices four years later. International Education Studies, 6(4): 154-163.

McPherron, P.R. (2008). Internationalizing teaching, localizing English: Language teaching reforms through a South Chinese university (Doctoral Dissertation). Davis, CA: University of California, Davis.

Mundy, K., Manion, C., Masemann, V. \& Haggerty, M. (2007). Charting global education in Canada's elementary schools: Provincial, district and school level perspectives. Toronto: UNICEF.

Mwebi, B.M. \& Brigham, S. M. (2009). Preparing North American pre-service teachers for global perspectives: An international teaching practicum experience in Africa. The Alberta Journal of Educational Research, 55(3), 414-427.

Olmedo, I., \& Harbon, L. (2010). Broadening our sights: Internationalizing teacher education for a global arena. Teaching Education, 21(1), 75-88.

Ontario Ministry of Education (2009). The Ontario curriculum, grades 1-8: The Arts. Retrieved from http://www.edu.gov.on.ca/eng/curriculum/elementary/arts18b09curr.pdf

Ontario Ministry of Education (2007). The Ontario curriculum grades 1-8: Science and Technology. Retrieved from http://www.edu.gov.on.ca/eng/curriculum/elementary/scientec18currb.pdf

Pieterse, J. N. (2003). Globalization and culture. Rowman \& Littlefield.

Porter, C. (2011). International English teacher education in South Korea. (Doctoral Dissertation). Pennsylvania State University, Penn State, PA.

Roberts, A. (2007). Global dimensions of schooling: Implications for internationalizing teacher education. Teacher Education Quarterly, 31(1), 9-26. 
Ryan, J., Pollock, K., \& Antonelli, F. (2009). Teacher diversity in Canada: Leaky pipelines, bottlenecks, and glass ceilings. Canadian Journal of Education, 32(3), 591-617.

Schneider, A. I. (2003). Internationalizing teacher education: What can be done? Washington, DC: United States Department of Education.

Shaklee, B.D. \& Baily, S. (2012). Introduction: A framework for internationalizing teacher education. In B.D. Shaklee \& S. Baily (Eds.), Internationalizing teacher education in the United States (pp. 1-13). Lanham, MD: Rowman \& Littlefield Publishers.

Stake, R. E. (1988). Case study methods in educational research. In R. M. Jaeger (Ed.), Complementary methods for research in education (pp. 253-300). Washington, DC: American Educational Research Association.

Stake, R. E. (1994). Case study. In N.K. Denzin \& Y.S. Lincoln (Eds.), Handbook of qualitative research (pp. 236-47). Thousand Oaks, CA: Sage.

Statistics Canada (2013). Immigrant and ethnocultural diversity in Canada. National household survey, 2011. Ottawa: Ministry of Industry.

Stromquist, N. P. (2007). Internationalization as a response to globalization: Radical shifts in university environments. Higher Education, 53(1), 81-105.

Tiessen, R. (2012). Motivations for learning/volunteer abroad programs: Research with Canadian youth. Global Citizenship and Equity Education Journal, 2(1), 1-21.

Trent, J. \& DeCoursey, M. (2011). Crossing boundaries and constructing identities: The experiences of early career Mainland Chinese English language teachers in Hong Kong. Asia-Pacific Journal of Teacher Education, 39(1), 65-78.

Trilokekar, R.D. \& Kukar, P. (2011). Disorienting experiences during study abroad: Reflections of pre-service teacher candidates. Teaching and Teacher Education, 27, 1141-1150. 
Tudball, L. (2012). Global perspectives on the internationalization of teacher education: Through an Australian lens. In B.D. Shaklee \& S. Baily (Eds.), Internationalizing teacher education in the United States (pp. 93-112). Lanham, MD: Rowman \& Littlefield Publishers.

Tye, K. A. (2004). Global education as a worldwide movement. Phi Delta Kappan, 85(2), 165-168.

UNICEF Canada (2013). Strengthening global education training in Canadian faculties of education: UNICEF Canada final evaluation report on the 2009-2012 Faculty of Education partnerships. Ottawa: CIDA.

Walsh, S., \& Brigham, S. (2008). Internationally educated teachers and teacher education programs in Canada: Current practices. Halifax, NS: Atlantic Metropolis Centre.

Walters, L. M., Garii, B., \& Walters, T. (2009). Learning globally, teaching locally: incorporating international exchange and intercultural learning into pre-service teacher training. Intercultural Education, 20(Suppl.1), S151-S158.

Wang, C., Dong, J. \& Shibata, M. (2009). Comparative education in two Asian contexts: A juxtaposition and some questions. In R. Cowen \& A. Kazamias (Eds.), International Handbook of Comparative Education (pp. 1209-1322). Dordrecht: Springer.

Western Education (2015). Teacher education- Western University: Cohort choices. Retrieved from http://www.edu.uwo.ca/programs/preservice-education/index.html\#program 